\title{
Labour migration in southern and eastern England, 1861-1901
}

\author{
GEORGE R. BOYER \\ Department of Labor Economics, School of Industrial and Labor Relations, \\ Cornell University, Ithaca, NY 14853-3901, USA
}

\begin{abstract}
This paper examines the determinants of migration from 19 southern counties to six major destinations in England and Wales from 1861-70 to 1891-1900.1 find that, while the size of origin-destination wage gaps and the distance between origin and destination areas were important determinants of migration flows, as expected, migration was also strongly influenced by the number of previous migrants from an origin county living in a destination. The assistance provided by previous migrants to friends and relatives contemplating migration led to a perpetuation of earlier migration patterns, and helps to explain the continued dominance of London as a destination for migrants in the 1890s.
\end{abstract}

\section{Introduction}

From 1841 to 1901 the 'rural residues' of England and Wales lost 4.2 million individuals as a result of migration (Cairncross 1949, p. 83). Nearly twothirds of these rural migrants $(2.7 \mathrm{~m}$.) came from southern England. Large numbers of rural registration districts throughout southern England, from East Anglia to Cornwall, experienced such high outmigration rates that, despite relatively high rates of natural increase, their population declined from 1851 to 1911 (Lawton 1967, p. 244). During this same period English cities gained nearly $3 \mathrm{~m}$. people through migration and the English and Welsh coal districts gained over 500,000; approximately 700,000 people emigrated. London was by far the most important destination for migrants. From 1841 to 1901 net migration to London equalled $1.48 \mathrm{~m}$., while migration to the northern cities of Manchester, Liverpool, Leeds, Sheffield, and Hull equalled 752,000, and migration to the Midlands cities of Birmingham, Nottingham, and Leicester totalled 231,000 (Cairncross 1949, p. 86). ${ }^{1}$

The literature on internal migration in late nineteenth century England and Wales is quite large. In particular, there have been several studies of the extent and causes of rural depopulation, and of the role played by migration

During the same period migration into the South Wales coalfield equalled 243,000, and migration to the northeastern coalfield totaled 261,000 (Cairncross 1949, p. 86). 
in the growth of cities. ${ }^{2}$ However, there have been surprisingly few empirical analyses of the determinants of migration flows. The recent studies by Morgan (1985) and Friedlander (1992) focused on trying to explain variations in the rate of migration into or out of counties or registration districts rather than on the flow of migration from one particular area to another. ${ }^{3}$ While these studies yield important information concerning why individuals left origin counties, they do not tell us how migrants chose their destinations.

This paper examines the determinants of male migration flows from 19 southern counties to six major destinations from 1861 to $1901 .^{4}$ Previous studies of net migration rates at the county level by Hunt (1973, pp. 243-50) and at the registration district level by Friedlander (1992) have shown that 'the overall influence of migration was to transfer population from low- to high-wage areas.' In this paper I attempt to explain how potential migrants from low-wage southern counties chose their destinations from among several high-wage areas. I find that, while the size of rural-urban wage gaps played an important role in determining migration patterns, migration was also strongly influenced by distance and by previous migration flows. Indeed, the migration patterns of the 1880 s and 1890s cannot be understood without taking into account the assistance provided by previous migrants living in a destination to friends and relatives in low-wage areas contemplating migration.

In the paper's final section I examine movements over time in rural-urban

2 On rural depopulation, see for example Eversley (1907), Bowley (1914), Saville (1957)5 and Lawton (1967). On the role played by migration in the growth of cities, see Ravenstein (1885), Weber (1899), Shannon (1934-5), Cairncross (1949), and Friedlander (1974).

${ }^{3}$ Friedlander (1992) analyses the direction of migration flows for one decade, 1861-70. Two earlier studies, by Greenwood and Thomas (1973) and Vedder and Cooper (1974), did analyse the direction of migration flows. Both papers use as their dependent variable the stock of individuals born in an origin county and living in a destination county in a given year $t$ (1861 and 1851, respectively), and as independent variables the wage rates in origin and destination observed only in year $t$. Because the stock of migrants living in a destination at a point in time is a proxy for the cumulative flow of migrants to the destination in the previous 30-40 years, these papers attempt to explain migration flows that occurred from 1821 to 1861 using origin and destination wage data for 1861. If wage rates in 1861 were influenced by migration flows from 1821 to 1861 , such a procedure clearly produces biased results.

${ }^{4}$ Females comprised about 48 per cent of the outmigrants from the 19 southern counties from 1861 to 1901 (Baines 1985, pp. 285-92). I focus on male migration because the lack of female wage data makes it difficult to determine the causes of female migration. Morgan (1985) and Friedlander (1992) used male agricultural wage rates as a proxy for female wage rates in their regressions to explain female migration rates. However, domestic service was by far the most important occupation for women even in the rural southern counties (Lee 1979). Neither Morgan nor Friedlander offers evidence that male agricultural wages are a good proxy for the wages of female domestic servants. 
wage differentials. Despite strong migration flows from low-wage agricultural counties to high-wage urban areas, wage gaps declined only slightly from 1861 to 1901, which supports Hunt's conclusion (Hunt 1973, p. 242) that the effects of migration were countered by 'strong [demand] forces working to reinforce existing wage differentials.'

\section{The determinants of migration}

Economists typically maintain that an individual's decision to migrate is determined by a comparison of economic conditions at home (in this case in the origin county) and in possible destinations. An individual will choose to migrate from one county to another if he or she believes that the benefits from moving, typically proxied by the difference in wages between origin and destination counties, exceed the (monetary and psychic) costs of the move, which often are proxied by the distance between origin and destination. Distance also is a proxy for information on urban labour markets: as distance increases, information concerning job opportunities declines. The effect of distance on migration was first noticed by Ravenstein (1885, pp. 198-9), who analysed the birthplace data from the 1881 British census and concluded that 'the great body of our migrants only proceed a short distance ... Migrants enumerated in a certain centre of absorption will consequendy grow less with the distance proportionately to the native population which furnishes them.' More recent studies have confirmed Ravenstein's hypothesis concerning the importance of distance in determining migration patterns. For example, Smith (1951, p. 210) concluded from his study of migration in 1851 and 1861 that 'each industrial region possessed a "sphere of attraction" ... With the exception of London and the contribution made by the Irish to the growth of population in Lancashire, each industrial region recruited by far the greater part of its labour in a zone of which the radius was rarely more than fifty miles and usually less.' Friedlander and Roshier (1966) present further evidence of the importance of distance in determining migration patterns in the second half of the nineteenth century. ${ }^{5}$

Ravenstein (1885, pp. 205-6) argued that, while most cities 'recruit their population in the main from the county in which they are situated' and from adjacent counties, London's demand for labour was so large that it could not be supplied by the surrounding counties, and as a result the metropolis attracted large numbers of migrants from all over southern England. Several historians also have noted the exceptional drawing power of London. Smith (1951, p. 210) found that, in the 1850s, among English cities 'London alone drew in large quantities upon areas that were up to and even over a hundred miles distant.' Hunt (1973, pp. 281-2) concluded that 'a large part of the

5 See also Smith (1892), Shannon (1934-5), ${ }^{\text {an }}$ d Friedlander (1974) on the effect of distance on migration to London. 
southern labour force appears to have operated in a particularly restricted market. They moved overwhelmingly in one direction - towards London.'

It often is argued that rural-urban migration was driven by differences in expected income rather than by simple wage differentials. ${ }^{6}$ New migrants to cities might not immediately find jobs if urban areas have significant levels of unemployment. A new migrant's expected urban income typically is assumed to be equal to the urban wage times the urban employment rate (one minus the unemployment rate). The expected income gap is therefore equal to $\left[\mathrm{Wj}(\mathrm{i}-\mathrm{Uj})-\mathrm{WJ} / \mathrm{W}_{\mathrm{i} 3}\right.$ where $\mathrm{W}_{3}$ is the destination (urban) wage rate and $\mathrm{Uj}$ is the destination unemployment rate. Thus, it is possible that the cities with the highest wage rates did not have the highest expected incomes for potential migrants.

Some historians have stressed that migration decisions were based not only on wage rates and employment rates but also on the type of employment available in destinations. Hunt (1973, pp. 283-4; ${ }^{\mathrm{I}} 98 \mathrm{i}$, p. 157) and Baines (1985, p. 218) maintained that migrants from agriculture preferred employment in transport, distribution, or other service occupations to factory employment. The recent study by Friedlander (1992) offers evidence in support of this view. He found that the share of a destination county's male labour force employed in the tertiary sector had a significant positive effect on inmigration from agricultural counties in 1861-70 (Friedlander 1992, p. 313). Service employment varied significantly across destination regions, being high in Greater London and relatively low in the industrial north and Midlands (Lee 1984, pp. 148-51).

One final factor that needs to be considered is the effect of past migration on current migration flows, the so-called 'friends and relatives' effect. The presence of friends or relatives in a destination performed three functions for individuals in the origin area contemplating migration. First, they provided information on wage rates, employment opportunities, and amenities/ disamenities in the destination. Second, they lowered the costs of job search by financially supporting new migrants until they found employment. Finally, the existence of friends and relatives reduced the psychic costs of migration.

None of the previous studies of internal migration in Victorian Britain examined the effect of past migration on current migration flows. ${ }^{7}$ However, the importance of friends and relatives as a source of information to potential migrants was noted a century ago by Smith (1892, p. 134), who concluded that 'a country nucleus once established in any particular district of London, grows in geometric ratio by the importation of friends and

\footnotetext{
${ }^{6}$ See Todaro (1969), and Harris and Todaro (1970).

${ }^{7}$ This is unfortunate, since failure to include a measure of past migration in regression models has been shown to result in 'an overstatement of the current direct effects of other explanatory variables on migration' (Levy and Wadycki 1973, p. 202; Greenwood 1972-3, PP- 27-30).
} 
relations. We find one village sending the flower of its youth to Finsbury, another to Hornsey, a third to a big establishment in Cheapside.' Hill (1925, p. 88) concluded from his study of migration from Essex that there was a strong 'tendency for children not only from the same family but from the same village to follow one another into the same town district and into similar employment,' and Kerr (1962, p. 176) found that 'even when improved education and greater familiarity with travel encouraged more country people to move in the 1870 's it was left to adventurous individuals to blaze the trail to some industrial centre, whither, if conditions were good, fellow villagers would migrate.' Hunt (1973, p. 282-3) also noted the tendency of migration streams from rural southern counties to perpetuate themselves. In his words, 'once set in a particular direction ties of family and friendship and especial knowledge of conditions in the receiving area make it likely that migration streams will continue.'

\section{Internal migration and choice of destination}

The principle source for the study of migration in nineteenth century Britain is the birthplace data recorded in the census. These data enable one to determine, for any given census year, the number of individuals born in a particular county who were living in every other county. The data can be used to estimate the decadal flow of migrants from one county to another. County-level birthplace data are available for each decade from 1851 to 1911. However, because the county definitions used in collecting the 1851 and 1911 birthplace data were not the same as those used in collecting the 1861-1901 data, I decided to use only the data for 1861 to $1901 .^{8}$

I focus on migration from southern and eastern England because of the enormous outflow from these regions in the second half of the nineteenth century. From 1851 to 1901 , net outmigration from the rural south and east totalled over $2.4 \mathrm{~m}$., compared to 982,000 from the rural north and 350,000 from rural Wales (Cairncross 1949, pp. 83-4). Of the 17 English counties with net outmigration greater than 50 per cent of their natural increase during the second half of the century, 13 were located in the south and east (Saville 1957, pp. 50). There were many reasons for the relatively high outmigration rates from southern counties. Migration was greatest from agricultural districts, and the south and east were the most agricultural regions in England. Moreover, agricultural wages in the south and east were among the lowest in England throughout the second half of the nineteenth century (Hunt 1986, pp. 965-6; Boyer 1995, pp. 12-14).

In this section I examine the direction of migration flows from 19

${ }^{8}$ Baines (1985, p. 95) concluded that 'in theory, it would have been possible to convert the 1911 and 1851 enumerations to Ancient county bases, but it was felt that it could not be done within an acceptable margin of error.' 
southern and eastern counties to six major urban destinations from 1861-70 to 1891-1900. A comment on the counties included in the analysis is in order. Birthplace data are only available at the county level of observation. Greater London, besides including virtually all of Middlesex, included parts of Kent, Surrey, and Essex. Thus, it was necessary to define the destination Greater London to include the entire counties of Middlesex, Kent, Surrey, and Essex, and as a result, these counties could not be included as origin counties. Similarly, because part of north Worcestershire was in the industrial district around Birmingham, I included Worcestershire in the West Midlands destination and not as an origin county.

I chose to include the eastern counties of Lincolnshire and Rutland as origin counties but not to include Gloucestershire. While Lincolnshire clearly is not in the south of England, historians of migration often have linked it with the eastern counties of Norfolk, Suffolk, and Cambridge. ${ }^{9}$ Gloucestershire is included in the Southwest by some historians and in the West Midlands by others. I chose not to include it because it was a relatively urban county with a small share of the population employed in agriculture.

There were six major destination regions for migrants from southern England in the late nineteenth century: London and the Home counties, Lancashire and Cheshire, Yorkshire, the West Midlands, the East Midlands, and South Wales. ${ }^{10}$ A seventh destination region for England and Wales as a whole, the northeastern coalfield, attracted few migrants from southern England, and for this reason is not included in the empirical analysis.

Table 1 presents the distribution of male migrants from the 19 southern counties living in each of the six major destination areas in 1861 and 1901. For expository purposes, the origin counties are grouped into five regions. ${ }^{11}$ Given that most migrants were young adults aged 15-35, the data for 1861 provide a measure of migration flows during the previous three or four decades, that is from 1821 or 1831 to i860, while the 1901 data provide a measure of migration flows from 1861 or 1871 to 1900.

\footnotetext{
${ }^{9}$ See, for instance, Bowley (1914), Cairncross (1949), and Saville (1957).

${ }^{10}$ Saville (1957, pp. 44-7) does not include the East Midlands as a major destination area for migrants. However, from 1861 to 1901 Leicester, Nottingham, and Derby, the three major East Midlands' cities, increased in population by 381,000, only slightly less than Birmingham's increase of 409,000 (Mitchell and Deane, 1962, pp. 24-7). Moreover, Cairncross (1949, p. 86) estimates that net migration to Leicester and Nottingham from 1861 to 1901 was 70,000, while net migration to Birmingham during the same period was 67,000. These data suggest that the East Midlands was indeed a major destination area.

${ }^{11}$ The counties included in each region are: Southeast - Sussex, Hampshire; South Berkshire, Hertford, Bedford, Buckingham, Oxford; East - Cambridge, Huntingdon, Suffolk, Norfolk; Southwest - Wiltshire, Dorset, Devon, Cornwall, Somerset; Rural East Midlands - Northampton, Lincoln, Rutland.
} 
Table 1. Distribution of male migrants fnim southern regions living in destination areas, 1861 and 1901 (\%).

\begin{tabular}{|c|c|c|c|c|c|c|}
\hline \multirow[t]{2}{*}{ Region } & \multicolumn{6}{|c|}{ Destination area } \\
\hline & London & Lancashire & Yorkshire & $\begin{array}{l}\text { West } \\
\text { Midlands }\end{array}$ & $\begin{array}{l}\text { East } \\
\text { Midlands }\end{array}$ & $\begin{array}{l}\text { South } \\
\text { Wales }\end{array}$ \\
\hline \multicolumn{7}{|l|}{1861} \\
\hline Southeast & 89.1 & 34 & $1-9$ & 2.9 & 1.2 & 1.6 \\
\hline South & 80.8 & $3-0$ & 2.3 & 10.5 & 2.1 & i-3 \\
\hline East & 81.0 & $4-7$ & $7-5$ & 3.2 & 2.7 & 0.9 \\
\hline Southwest & 64.0 & 6.3 & 2.8 & 6.2 & $i-5$ & 19.2 \\
\hline \multicolumn{7}{|l|}{ Rural East } \\
\hline Midlands & 30.6 & $7-2$ & 27.9 & 12.1 & 21.4 & 0.8 \\
\hline \multicolumn{7}{|l|}{1901} \\
\hline Southeast & 86.0 & 4.2 & 2.9 & $3-0$ & $1-9$ & 2.1 \\
\hline South & $73-7$ & $4-8$ & 5.1 & $9-5$ & $5-2$ & 1.8 \\
\hline East & 69.6 & 7.0 & 13.6 & 3.2 & 5.6 & 1.0 \\
\hline Southwest & 55.0 & 8.1 & 4.6 & & 2.7 & 23.9 \\
\hline Rural East & & & & 5.8 & & \\
\hline Midlands & 22.8 & 10.0 & 32.0 & & 25.8 & 0.9 \\
\hline
\end{tabular}

Source: 1861 and 1901 Population Censuses.

Two results stand out in Table 1. The first is the overwhelming importance of London as a destination for southern migrants. With the exception of the rural East Midlands (Northampton, Lincoln, and Rutland), the majority of migrants from rural southern counties moved to London or the Home counties. The relative importance of London as a destination varied with distance from the origin counties. In the Southeast and most of the South and East, London was the closest of the major destinations and attracted 70-90 per cent of migrants. For most of the Southwest the closest destination was South Wales, and in some areas Birmingham was closer than London, and yet London still attracted a majority of migrants. Only in the rural East Midlands, large parts of which were closer to Leicester, Nottingham, Sheffield, or Hull than to London, did London attract less than a majority of migrants, and even there London attracted more migrants than any other destination from 1821 to i860.

The second result that stands out is the similarity between the distribution of migrants in 1861 and 1901. The relative importance of London as a destination declined from 1861 to 1901 for each rural region, and yet outside the rural East Midlands London was still the dominant destination of migrants. Even in the Southwest, where London's share of migrants 
198 European Review of Economic History

declined by 14 per cent from 1861 to 1901 , in 1901 London still attracted more than twice as many migrants (55 per cent) as the second most popular destination. South Wales (24 per cent). The one exception was the rural East Midlands, where London's share of migrants declined by 25 per cent; by 1901 London was only the third most popular destination for migrants from the region, behind Yorkshire and the East Midlands. On the whole, however, the results in Table 1 indicate that migration flows from southern England in 1861-1900 were quite similar to those in 1821-60.

The data in Table 1 represent a stock of migrants who were born in one county but living in another at a particular point in time. It is possible, however, to use the birthplace data contained in the census to estimate the flow of migrants from one county to another for each decade 1861-70 to 1891-1900. I have estimated the number of migrants from the 19 southern and eastern counties to each of the six major destinations for each decade, using the following method. I begin by subtracting the stock of migrants from, say, Suffolk living in London and the Home counties in 1861 from the stock living there in 1871. This gives an underestimate of the number of individuals who migrated from Suffolk to London in 1861-70, because some of the previous migrants living in London in 1861 would have died by 1871 , and thus would not have been counted in the 1871 census. It is therefore necessary to estimate the number of Suffolk-born individuals living in London who died between 1861 and 1870. Such a calculation requires three sets of numbers: the age distribution of Suffolk-born individuals living in London in 1861; the age distribution of migrants from Suffolk to London during the decade 1861-70; and a survival table indicating the probability that a Suffolk-born individual of a certain age living in London in 1861 will die by 1871 .

My estimate of the age distribution of individuals born in each origin county and living in each destination in 1861, obtained from Baines (1985, p. 106), is as follows: 2 per cent aged $0-4,10$ per cent aged 5-14, 23 per cent aged 15-24, 19 per cent aged 25-34, J 8 per cent aged 35-44, 14 per cent aged 45-54, 9 per cent aged 55-64, 4 per cent aged 65-74, and 1 per cent over age 75 . These numbers represent an estimate of the age distribution as of 1861 of the surviving individuals who migrated to the destination during the previous four or five decades. I assume that the age distribution in 1861 is the same for each of the 114 origin-destination combinations (19 origin counties X 6 destinations). My estimate of the age distribution of migrants from each origin county to each destination during each of the four decades, also obtained from Baines (1985, p. 104), is as follows: '4 per cent aged $0-4,15$ per cent aged 5-14, 53 per cent aged $15-24 \ldots$ and 28 per cent aged 25-34.' Finally, I used the age-specific mortality tables in the annual reports of the Registrar General to calculate survival ratios for each destination for each decade. Thus, I assume that the life expectancy of an individual who migrates to London from Suffolk is determined, once he gets 
to London, by mortality tables for London, rather than by some combination of mortality tables for Suffolk and London. ${ }^{12}$

Given these three sets of numbers, one can estimate the number of Suffolk-born individuals who died in London during the decade 1861-70. The number of migrants from Suffolk to London in 1861-70 can then be calculated as:

$$
\operatorname{MIG}\left(6 \mathrm{i}_{-7} \mathrm{o}\right) \mathrm{ij}=(\operatorname{MS}(7 \mathrm{i}) \mathrm{ij}-\mathrm{MS}(6 \mathrm{i}) \mathrm{ij})+\mathrm{D}(6 \mathrm{i}-7 \mathrm{o}) \mathrm{ij}
$$

where MIG(6I-70);J refers to the number of migrants from county $i$ to destination.;'in 1861-70, $\left.\mathrm{MS}^{\wedge} \mathrm{i}\right)^{\wedge}$ is the stock of individuals born in county $i$ and residing in destination; in 1871 , and $\mathrm{D}(6 \mathrm{I}-7 \mathrm{O})$; $\mathrm{J}$ refers to the number of individuals born in county $i$ and residing in destination $j$ who died between 1861 and 1870. The new migrants (MIG(6i-70)jj) are then given an age distribution as of 1871 (discussed above) and added to the remaining migrants who arrived in the destination before 1861 but survived until 1871 . The steps outlined above are then repeated using the stock of migrants in 1881 and the age distribution of the migrant stock as of 1871 to calculate the number of migrants during 1871-80. ${ }^{13}$

Because the migration estimates are based on assumptions concerning the age distribution of the 1861 migrant stock, the age distribution of current migrants, and the age-specific mortality of migrants, they are subject to

${ }^{12}$ Because age-specific mortality was higher in large urban areas than elsewhere in England and Wales, my use of destination survival ratios will produce an overestimate of migrant deaths if the age-specific mortality of migrants was influenced by the location in which they were born and raised. Baines (1985, pp. 109-10) argues that mortality calculations based entirely on 'nurture' influences, as those here, will yield an upper bound estimate of migrant deaths, while calculations based on the mean mortality of England and Wales will yield a lower bound estimate of migrant deaths. Friedlander and Roshier (1966) base their estimates of migrant deaths on the mean mortality of England and Wales.

${ }^{13}$ The method used here will produce an underestimate of rural-urban migration to the extent that migrants from rural southern counties to urban destinations later emigrated. For example, a person who migrated from Suffolk to London in 1864 and then emigrated in 1868 would not be counted as a migrant to London (because he or she would not be listed as a London resident in the 1871 Census), while a person who migrated from Suffolk to London in 1868 and then emigrated in 1872 would be counted as a migrant to London in the 1860s but would mask the migration of a Suffolk-born individual to London during the 1870s (because he or she would be listed as a London resident in the 1871 Census but not in the 1881 Census). However, Baines (1985, pp. 253-7) ${ }^{\text {nas }}$ shown that the extent of such rural-urban stage emigration was relatively small during this period, especially among migrants born in the southern counties included in this study. Baines (1985, p. 263) also found that 'the share of stage emigrants was probably about the same in all industrial areas except in South Wales where it was probably high.' The high rate of stage emigration from South Wales involved mainly migrants from rural Wales rather than from the Southwest of England (Baines 1985, pp. 255-6). The method used here therefore should yield reliable estimates of both the size and direction of ruralurban migration flows from southern counties. 
error. Of these, the estimated age distribution of new migrants is the most important, 'because an error in the assumption of the current migrant age distribution is cumulative, whereas an error in age-specific mortality and in the initial age distribution of lifetime migrants is not' (Baines 1985, pp. 99-100). To determine the effect on the migration estimates of my assumptions concerning age distribution, I calculated the migration flows four times, using alternative estimates of the age distribution of the 1861 migrant stock and the age distribution of current migrants obtained from Baines (1985, pp. 105-7). The alternative estimate of the age distribution of current migrants assumes that migrants were somewhat older than in the preferred estimate: 4 per cent aged 0-4, 15 per cent aged 5-14, 33 per cent aged 15-24, 25 per cent aged $25-34,{ }^{\mathrm{J}} 5 \mathrm{P}^{\mathrm{ercent}}$ aged $35-44 \mathrm{~J}^{\text {an }} \mathrm{d} 8$ per cent aged $45-54 .{ }^{14}$ The four calculations yielded migration estimates that were quite similar, which suggests that the estimated migration rates are reasonably accurate.

The resulting estimates of migration flows from rural southern counties to the six major destinations for each decade 1861-70 to 1891-1900 are presented in Table 2. As before, the origin counties are grouped into five regions. The Southeast sent more than 80 per cent of its migrants to Greater London in each decade. The South and East both sent 70-75 per cent of their migrants to London in the 1860s, 1880s, and 1890s, but a far smaller share went to London in the 1870s. The aberration of the 1870s was especially pronounced in the East, where from the 1860s to the 1870s the share of migrants going to London fell from 71.1 per cent to 52.5 per cent and the share going to Lancashire /Yorkshire increased from 22.9 per cent to 45.2 per cent. In the 1880 s, however, the share going to London returned to its 1860 s level, and the share going to Lancashire/Yorkshire declined to 19 per cent.

The Southwest experienced significant declines in the share of migrants going to London in both the 1870s and 1880s, when London's share fell below 50 per cent. The decline in the attractiveness of London was more than offset by a sharp rise in the 1880s in the share of migrants going to South Wales. However, in the 1890s the percentages of migrants going to London and South Wales returned to about their 1860s levels.

The most significant long run changes in migration flows occurred in the rural East Midlands. In the 1860s the dominant destination of East Midlands migrants was Yorkshire. The share of migrants going to Yorkshire declined steadily, however, from 42.4 per cent in the 1860 s to 28.6 per cent in the 1890s. At the same time, the share going to the urban East Midlands

14 The alternative estimate of the age distribution of the 1861 migrant stock is: 1.1 per cent aged $0-4,5.8$ per cent aged 5-14, 23.4 per cent aged 15-24, 26.3 per cent aged 25-34, 14.5 per cent aged $35-44,13.3$ per cent aged 45-54, 9.4 per cent aged 55-64, 5.0 per cent aged $65-74,{ }^{\text {an }} \mathrm{d} 1.1$ per cent over age 75 . 
Table 2. Share of migrant flows from southern regions to destination areas, $1860 \mathrm{~S}-1890 \mathrm{~S}(\%)$.

\begin{tabular}{|c|c|c|c|c|c|c|c|}
\hline Region & $\begin{array}{l}\text { No. of } \\
\text { migrants }\end{array}$ & London & Lancashire & Yorkshire & $\begin{array}{l}\text { West } \\
\text { Midlands }\end{array}$ & $\begin{array}{l}\text { East } \\
\text { Midlands }\end{array}$ & $\begin{array}{l}\text { South } \\
\text { Wales }\end{array}$ \\
\hline \multicolumn{8}{|l|}{ Southeast } \\
\hline $1860 \mathrm{~s}$ & 25,391 & 85.7 & $4-5$ & 4.2 & 2.5 & 1.6 & 1.6 \\
\hline $1870 \mathrm{~s}$ & 32,651 & 82.5 & 6.0 & 4.2 & 3.2 & 2.3 & 1.8 \\
\hline $1880 \mathrm{~s}$ & $3 i>724$ & 83.9 & 6.1 & $1-9$ & 2.4 & $1-9$ & 3-7 \\
\hline $1890 \mathrm{~s}$ & 34,638 & 88.5 & 2.0 & 2.6 & $3-5$ & i-9 & 1.4 \\
\hline \multicolumn{8}{|l|}{ South } \\
\hline $1860 \mathrm{~s}$ & $35^{\wedge} 78$ & 74-7 & 6.4 & 6.1 & 8.2 & 3-5 & 1.1 \\
\hline $1870 \mathrm{~s}$ & $43 * 862$ & 64.8 & 6.5 & $9-i$ & $9-4$ & $9-1$ & 1.2 \\
\hline $1880 \mathrm{~s}$ & 34,026 & 75.6 & $6-3$ & $3-5$ & 6.8 & 4-7 & 3.0 \\
\hline $1890 \mathrm{~s}$ & 41,406 & 75.0 & 2.9 & 3-9 & 11.5 & 4-6 & 2.1 \\
\hline \multicolumn{8}{|l|}{ East } \\
\hline $1860 \mathrm{~s}$ & 39,621 & 71.1 & 6.6 & 16.3 & 2.6 & 3-1 & 0.3 \\
\hline $1870 \mathrm{~s}$ & $43 * 767$ & 52.5 & 11.8 & 23.4 & $3-7$ & $7-8$ & 0.8 \\
\hline 188OS & $35 * 635$ & 71.4 & 9.9 & $9-1$ & 2.3 & 54 & 2.0 \\
\hline $1890 \mathrm{~s}$ & $39 * 650$ & 74-9 & 3.0 & 10.3 & 4.0 & 6.8 & 1.0 \\
\hline \multicolumn{8}{|l|}{ Southwest } \\
\hline $1860 \mathrm{~s}$ & $47 * 378$ & 58.6 & 8.7 & $7-3$ & 4-7 & 1.6 & 19.0 \\
\hline $1870 \mathrm{~s}$ & 59,161 & 51.1 & 14.5 & 7-6 & $5-7$ & 4.1 & 17.0 \\
\hline $1880 \mathrm{~s}$ & $43 * 7$ i6 & 46.4 & 6.2 & 1.0 & $3-4$ & 2.1 & 40.9 \\
\hline $1890 \mathrm{~s}$ & 42,743 & 56.8 & 4.8 & 3-9 & 8.6 & $3-1$ & 22.7 \\
\hline \multicolumn{8}{|c|}{ Rural East Midlands } \\
\hline $1860 \mathrm{~s}$ & $29 * 559$ & 25.0 & $9-2$ & 42.4 & 5.8 & 17.3 & 0.4 \\
\hline $1870 \mathrm{~s}$ & 30,992 & 19.1 & 12.2 & 32.7 & 7.8 & $27-5$ & 0.8 \\
\hline $1880 \mathrm{~s}$ & $3 i * 335$ & 21.1 & 14.5 & 30.3 & 6.4 & 26.2 & 1.6 \\
\hline $1890 \mathrm{~s}$ & 28,208 & 21.7 & 7-4 & 28.6 & 11.0 & 30.4 & 1.0 \\
\hline \multicolumn{8}{|l|}{ Overall } \\
\hline $1860 \mathrm{~s}$ & 177,107 & 62.9 & 7-3 & 14.5 & 4.8 & 4-9 & $5-7$ \\
\hline $1870 \mathrm{~s}$ & 210,433 & $54-4$ & 10.6 & 14.3 & 6.0 & $9-1$ & $5-6$ \\
\hline 1880 s & 176,436 & 59-3 & 8.4 & 8-5 & 4.2 & $7-5$ & 12.1 \\
\hline $1890 \mathrm{~s}$ & 186,645 & 65.3 & 3-9 & 8.7 & $7-7$ & 8.1 & 6.3 \\
\hline
\end{tabular}

Source: Calculated by author from 1861 through 1901 Population Censuses.

increased from 17.3 per cent to 30.4 per cent. The share of migrants going to London declined slightly, from 25 per cent in the 1860 s to 21.7 per cent in the 1890 s.

It is useful to compare the overall migration flows during the four decades, which appear in the bottom panel of Table 2 , with the trends in 
destination wage rates which are presented in Table $3 .{ }^{15}$ Panel A shows that nominal wage rates in London were 18-27 per cent higher than wages in any

Table 3. Trends in relative destination wage rates, 1861-1891.

\begin{tabular}{|c|c|c|c|c|c|}
\hline Destination & 1861 & 1871 & 1881 & 1891 & $\begin{array}{l}\% \text { increase in } \\
\text { wage rates, } \\
1861-1891\end{array}$ \\
\hline \multicolumn{6}{|c|}{ Panel A: Nominal wage rates } \\
\hline London & 100.0 & 100.0 & 100.0 & 100.0 & 18.2 \\
\hline Lancashire & 81.6 & 85.0 & 90.4 & $93-3$ & $35-1$ \\
\hline Yorkshire & 76.4 & 81.4 & 82.9 & 85.1 & 31.6 \\
\hline West Midlands & 79.5 & 83.0 & 91.6 & 96.6 & 43.6 \\
\hline East Midlands & 75.8 & 79.0 & $94-9$ & 92.9 & $44-9$ \\
\hline South Wales & 72.7 & 79.0 & 88.0 & 92.3 & 50.0 \\
\hline \multicolumn{6}{|c|}{ Panel B: Real wage rates } \\
\hline London & 100.0 & 100.0 & 100.0 & 100.0 & \\
\hline Lancashire & 88.7 & 92.4 & 98.3 & 101.4 & \\
\hline Yorkshire & 83.0 & 88.5 & 90.1 & 92.5 & \\
\hline West Midlands & 86.4 & 90.2 & 99.6 & 105.0 & \\
\hline East Midlands & 82.4 & 85.9 & 103.2 & 101.0 & \\
\hline South Wales & 79.0 & 85.9 & $95-7$ & 100.3 & \\
\hline
\end{tabular}

Source: See text.

other destination in the 1860s. However, from 1861 to 1891 wages in each of the other destinations increased more rapidly than London wages. By 1891 nominal wages in the West Midlands were within 4 per cent of those in London, and wages in Lancashire, the East Midlands, and South Wales were within 8 per cent of London wages. A 1905 survey of urban living costs by the Board of Trade found that the cost of living was at least 10 per cent higher in London than in other major English cities, largely because of the high cost of housing in the metropolis (Board of Trade 1908b, p. xlvi). Available evidence on urban rents in the 1880s suggests that the difference in living costs between London and other major cities was somewhat smaller in the late nineteenth century than in 1905. Panel B presents relative real wage rates for destination areas, assuming that the cost of living in provincial cities

15 The destination wage is measured as 0.67 times a weighted average of carpenters' weekly wage rates in each of the destination's major cities at the beginning of the decade. For evidence that the ratio of labourers' to skilled workers' wages in the building trades remained roughly constant over time, see footnote 18 . 
was 8 per cent below that in London. ${ }^{16}$ By the early 1880 s, real wages in Lancashire and the West Midlands were within 2 per cent of those in London, and wages in the East Midlands were slightly higher than wages in London. A decade later real wages in London were virtually the same as wages in Lancashire, the East Midlands, and South Wales, and 5 per cent below real wages in the West Midlands.

Other things equal, the convergence of wage rates should have led to a decline over time in the share of migrants going to London. However, the data on overall migration flows from the 19 southern counties show that, while the share of migrants going to London declined sharply in the 1870s, it then increased in the 1880s and again in the 1890s to a level slightly higher than in the 1860s. A comparison of the 1860 s and the 1890 s shows that London's share of southern migrants remained roughly constant despite a sharp deterioration in the London wage relative to wages in each of the other destinations. In sum, the evidence in Tables 2 and 3 indicates that migration flows cannot be explained simply by looking at destination wage rates.

\section{Regressions to explain migration flows}

In this section I estimate some simple regressions to determine the effect of real wage gaps, distance, and previous migration (friends and relatives) on male migration flows from southern counties to the six major destinations for each decade 1861-70 to $1891-1900$. The dependent variable is $\mathrm{M}^{\wedge} / \mathrm{P}$; the number of migrants from origin county $i$ to destination $j$ during a decade, divided by the population of the origin county at the beginning of the decade.

The wage gap is measured as $(\mathrm{Wj}-\mathrm{Wj}) / \mathrm{W}_{\mathrm{is}}$ the difference between the destination and origin wages, divided by the origin wage. Origin county wages are measured as weekly wage rates in agriculture at the beginning of the decade. ${ }^{17}$ Because rural-urban migrants found employment in many

${ }^{16}$ Data on urban rents reported by Hunt (1973, p. 102) suggest that in $1884-5$ th $^{\text {e cost }}$ of housing in large northern cities was about 75 per cent of the cost of housing in London. In 1905 urban rents in northern cities were 55-60 per cent of rents in London. Food and fuel prices in northern cities in 1905 were only about 5 per cent below prices in London (Board of Trade 1908b, p. xlvi). There is no evidence that the ratio of food and fuel prices in London to prices in provincial cities was significandy different during the period 1861-91. If rent payments made up 15 per cent of urban workers' budgets and expenditures on food and fuel made up 85 per cent, then the cost of living in major provincial cities was about 8 per cent below the cost of living in London in the second half of the nineteenth century.

${ }^{17}$ County-level wage data for agricultural labourers were obtained from Bowley (1898, pp. 705,707 ). For 1861,1 used the average of wages in i860 and 1861 (columns 9 and 10); for 1871, wage data for 1869-70 (column 13); for 1881, wage data for 1880 (column 16); and for 1891, wage data for 1892 (column 17). Bowley (1914, p. 617) contends that 'agricultural wages are in close sympathy with wages ... for unskilled labour in the same neighbourhood.' 


\section{European Review of Economic History}

different occupations, there is no perfect measure of destination wage rates. Hunt (1973, p. 5) maintains that 'building labourers' rates are a good guide to the relative level of all unskilled wages in a particular district.' Wage data for building labourers are not available for major cities in each region before 1880. However, wage data for carpenters are available, and evidence for 1880-1906 suggests that the ratio of unskilled to skilled workers' wages in the building trades remained relatively constant over time, at about $0.67 .^{18}$ The destination wage therefore is measured as 0.67 times a weighted average of the weekly wage rates of carpenters in each of the destination's major cities at the beginning of the decade. Destination wages are deflated to adjust for differences in urban and rural living costs. ${ }^{19}$

Distance is included as a proxy for the monetary and psychic costs of migration, and for the extent of information about urban job opportunities. It is measured as the air-mile distance between the centre of the origin county and the major city in the destination, e.g. Birmingham in the West Midlands. If there was more than one major city in a destination region, then distance is measured to the nearest major city. Air-mile distance clearly is not a perfect proxy for the cost of migration. Railways and roads do not always go as the crow flies; because London was the focus of road and rail links it might have been more accessible to some migrants than other cities that were physically closer (Hunt 1981, p. 157). Moreover, it could be argued that with the completion of the rail network in the late nineteenth century the importance of distance to migration decisions should have declined. However, the work of Ravenstein (1885) and more recent historians have shown that distance was an important determinant of migration in the second half of the nineteenth century, and an examination of the birthplaces of migrants to large cities in the 1911 census indicates that urban areas continued to recruit a large share of their labour from surrounding counties at the end of the nineteenth century. ${ }^{20}$

Migrant stock is measured as the number of individuals born in county $i$ who were residing in destination $j$ at the beginning of the decade, divided by

${ }^{18}$ Carpenters' wage data were obtained from an unpublished 1908 Board of Trade report on Rates of Wages and Hours of Labour in Various Industries in the United Kingdom. Wage data for both bricklayers' labourers and carpenters are available for several cities for the period 1880-1906. For each city the ratio of labourers' wages to carpenters' wages remained roughly constant over time, at a level close to 0.67. Bowley (1901, p. 103) found that in nineteenth century London building labourers' wages were 'very nearly two-thirds of those of artisans.' Rowe (1928, p. 67) maintains that in the building trades 'the idea of equal and simultaneous changes in the wages of all grades of labour ... [was] regarded as natural by employers and employed.'

${ }^{19}$ Rural and urban cost-of-living indices for 1862 to 1904 were obtained from Boyer et al. (1994, pp. 10-12). From 1862-3 to $1891-3$ rural living costs declined by 10.8 per cent, while urban living costs declined by 6.6 per cent. Urban living costs were 7.7 per cent higher than rural living costs in 1862-3, increasing to 12.8 per cent higher in 1891-3.

${ }^{20}$ See Boyer et al. (1994, Table 2). 
the population of the origin county at the beginning of the decade. ${ }^{21}$ Destination population, a proxy for the size of the labour market, is included in specifications that do not include destination dummies. ${ }^{22}$ Decadal dummies are included to determine whether, other things equal, migration flows varied over time.

The model was estimated with and without origin county dummies and destination dummies. The origin county dummies pick up influences that affected a county's outmigration rate but should not have affected migrants' choices of destination, such as the extent of urbanization, the percentage of the county's adult males who were illiterate, or the percentage of a county's male population who were of 'prime migration age.' The destination dummies pick up influences that made a destination especially attractive or unattractive that are not measured by wage rates, such as occupational structure, disamenities, or poor relief policies.

The regression results are presented in Table 4. Under each specification of the model the origin-destination real wage gap, distance between origin and destination, and the size of the migrant stock had a significant effect on migration rates. The preferred results are those reported in column 4, which include both origin county and destination dummies and therefore represent a fixed-effects model. The elasticities of migration with respect to distance and wage gaps are large; a 10 per cent increase in distance between origin and destination led to a 10.2 per cent decline in migration, while a 10 per cent increase in the wage gap led to a 5.1 per cent increase in migration.

The existence of previous migrants had a strong positive effect on migration rates, with an elasticity of 0.49 . The regression model also was estimated with the dependent variable and migrant stock entered in levels rather than in logs. The results indicate that an increase of 1,000 in a county's migrant stock living in a destination at the beginning of a decade would cause the number of migrants from the county to the destination to increase by 243 during the decade. The importance of past migration as a determinant of current migration patterns is discussed below.

To test the hypothesis that migration decisions were based on differences in expected income rather than on simple wage differentials, I re-estimated the regression model in column 4 , substituting the expected real income gap for the real wage gap. The expected income gap is measured as [WJ(I-UJ) $\mathrm{WJ} / \mathrm{Wj}$, where $\mathrm{Wj}$ is the destination (urban) wage rate and $\mathrm{Uj}$ is the destina-

${ }^{21}$ Data on the birthplaces of individuals residing in each destination county were obtained from the 1861-91 censuses.

${ }^{22}$ The six destinations differed significantly in size. London had the largest population in each decade, the East Midlands and South Wales the smallest. In 1861 the populations of the East Midlands and South Wales were each equal to 21 per cent of the population of London and the Home Counties; by 1891 they had each fallen to 19 per cent. The population of Lancashire, the second largest destination, was equal to 70 per cent (67 per cent) of the population of London in 1861 (1891). 
206 European Review of Economic History

Table 4. Determinants of male migration rates from southern counties to six urban destinations.

\begin{tabular}{|c|c|c|c|c|c|c|}
\hline & \multicolumn{4}{|c|}{ Dependent variable: Log migration rate } & \multirow[b]{2}{*}{ (5) } & \multirow[b]{2}{*}{ (6) } \\
\hline & (1) & (2) & (3) & (4) & & \\
\hline Constant & -0.40 & -0.23 & 0.63 & 2.19 & 2.25 & 0.71 \\
\hline & $(\mathbf{I}-5 \mathbf{I})$ & $(0.72)$ & $(2.10)$ & $(4-68)$ & $(4.82)$ & $(0.40)$ \\
\hline Distance & -0.39 & -0.71 & -0.51 & -1.02 & -1.01 & -1.04 \\
\hline & $(446)$ & $(5.08)$ & $(5-83)$ & $(7-37)$ & $(7.38)$ & $(7.41)$ \\
\hline Wagegap & 0.21 & 0.29 & 0.30 & 0.51 & & 0.46 \\
\hline & $(2.41)$ & $(2.41)$ & $(3-23)$ & $(3.88)$ & & $(3-25)$ \\
\hline Migstock & 0.75 & 0.62 & 0.69 & 0.49 & 0.49 & 0.47 \\
\hline Destpop & $\begin{array}{c}(16.43) \\
0.17\end{array}$ & $\begin{array}{l}(9-67) \\
0.37\end{array}$ & $(14-73)$ & $(7-63)$ & $(7-72)$ & $(7-32)$ \\
\hline & $(2.23)$ & $(3-45)$ & & & & \\
\hline $\begin{array}{l}\text { Expected } \\
\text { income gap }\end{array}$ & & & & & $\begin{array}{c}\mathbf{0 . 4 8} \\
(4-38)\end{array}$ & \\
\hline $\begin{array}{l}\text { Service } \\
\text { employment }\end{array}$ & & & & & & $\begin{array}{c}0.51 \\
(0.85)\end{array}$ \\
\hline D1870S & $\begin{array}{c}0.13 \\
(1-75)\end{array}$ & $\begin{array}{l}\text { O.II } \\
(1.50)\end{array}$ & $\begin{array}{c}0.14 \\
(1.96)\end{array}$ & $\begin{array}{c}0.13 \\
(\mathbf{i}-75)\end{array}$ & $\begin{array}{c}0.08 \\
(0.95)\end{array}$ & $\begin{array}{c}0.13 \\
(1.64)\end{array}$ \\
\hline Di88os & $\begin{array}{r}-0.55 \\
(7.62)\end{array}$ & $\begin{array}{r}-0.54 \\
(7-30)\end{array}$ & $\begin{array}{r}-0.48 \\
(6.39)\end{array}$ & $\begin{array}{r}-0.40 \\
(4.87)\end{array}$ & $\begin{array}{r}-0.44 \\
(5.19)\end{array}$ & $\begin{array}{r}-0.51 \\
(3-40)\end{array}$ \\
\hline D1890S & $\begin{array}{l}-0.78 \\
(10.30)\end{array}$ & $\begin{array}{r}-0.79 \\
(9-99)\end{array}$ & $\begin{array}{r}-0.69 \\
(8-49)\end{array}$ & $\begin{array}{c}-0.62 \\
(6.56)\end{array}$ & $\begin{array}{r}-0.64 \\
(6.84)\end{array}$ & $\begin{array}{c}-0.74 \\
(4.42)\end{array}$ \\
\hline $\begin{array}{l}\text { Origin county } \\
\text { dummies }\end{array}$ & no & yes & no & yes & yes & yes \\
\hline $\begin{array}{l}\text { Destination } \\
\text { dummies }\end{array}$ & no & no & yes & yes & yes & yes \\
\hline $\mathrm{R}^{2}$ & 0.858 & 0.866 & 0.868 & 0.880 & 0.881 & 0.880 \\
\hline $\mathrm{N}$ & 452 & 452 & 452 & 452 & 452 & 452 \\
\hline
\end{tabular}

Notes: $t$ statistics are in parentheses. The dependent variable and all explanatory variables except for the dummy variables are defined in logs.

tion unemployment rate. Destination unemployment rates were constructed from unemployment data for members of the Amalgamated Society of Engineers in the major cities in each region. ${ }^{23}$ The results are presented in column 5 of Table 4 . The substitution of the expected income gap for the wage gap has little effect on the coefficients of the other explanatory variables. The elasticity of migration with respect to the expected income gap is slightly

23 The unemployment series used here are part of a much larger data set containing unemployment data for each local branch of the Amalgamated Society of Engineers in Britain, collected by Humphrey Southall and David Gilbert. For a discussion of the data, see Southall (1986); for evidence that the engineers' unemployment rates are a reasonable proxy for the experience of other groups, see Southall and Gilbert (1996). 
smaller than that with respect to the simple wage gap; a 10 per cent increase in the expected income gap led to a 4.8 per cent increase in migration.

It was noted in Section 2 that some historians maintain that rural migrants preferred employment in service occupations to factory employment. ${ }^{24}$ To determine the effect of a destination's occupational structure on migration I constructed a variable measuring the share of each destination's employed males with jobs in transport, distribution, and miscellaneous services in each decade, using the county-level employment estimates constructed by Lee (1979). ${ }^{25}$ The share of males employed in the service sector was higher in London than in any other destination in each decade. For example, in 189124.6 per cent of London's employed males worked in the service sector, followed by Lancashire/Cheshire with 15.9 per cent, South Wales (13.3 per cent), Yorkshire (12.2 per cent), the West Midlands (11.5 per cent), and the East Midlands (11.3 per cent).

I re-estimated the regression in column 4 with the share employed in services included as an explanatory variable. The results are presented in column 6 . The coefficient on the service employment variable was not significantly different from zero, which suggests that, when wage gaps, distance, and migrant stock are taken into account, differences across destinations in the extent of service sector employment were not a major determinant of migration flows in southern England. ${ }^{26}$

For each specification of the model, the coefficients on the time dummies for the 1880s and 1890s are negative and significantly different from zero, and the coefficient for the 1890s is larger in absolute value than the coefficient for the 1880s. This suggests that, other things equal, migration rates from southern and eastern counties to the six major destinations declined in the last two decades of the nineteenth century. The decline was not simply a result of increased emigration. Although there was a significant increase in the emigration rate from southern counties in the $1880 \mathrm{~s}$, emigration rates declined sharply in the 1890s (Baines 1985, pp. 238-40). One possible explanation for the decline in migration to the six destinations in the 1880s and 1890s is that southerners began to migrate to a new destination, or set of destinations, in the last two decades of the century. Cairncross (1949, p. 83) estimated that southern residential and military

${ }^{24}$ See, for example, Hunt (1973, pp. 283-4; 1981, p. 157) and Baines (1985, p. 218).

${ }^{25}$ The share of males employed in services was calculated as the number of males employed in industrial orders 22 (transport and communication), 23 (distributive trades), and 26 (miscellaneous services), divided by the total number of employed males. The occupations included in each industrial order are given in Lee (1979, pp. 22-3).

${ }^{26} \mathrm{I}$ also re-estimated the regression in column 3 with the share employed in services included as an explanatory variable, and I estimated the model with the share employed in services included but both destination population and the destination dummies excluded. In both regressions the coefficient on the service employment variable was small and not significantly different from zero. 
towns experienced a net inmigration of about 58,000 in the $1880 \mathrm{~s}$ and 156,000 in the 1890 s, compared to less than 25,000 per decade from 1851 to $1880 .^{27}$ After 1880 and especially after 1890 many rural southerners apparently chose to migrate to nearby and rapidly growing cities, such as Plymouth, Portsmouth, Brighton or Bournemouth, rather than to London or one of the major industrial destinations.

The regression results in Table 4 offer some clues as to why London remained the dominant destination of southern migrants in the 1890s despite the convergence of destination wage rates shown in Table 3. For one thing, migration flows were strongly affected by distance between origin and destination areas. For potential migrants in much of the south and east, London was significantly closer than any of the other major destinations. However, several southern counties that were closer to cities in the Midlands or to South Wales than to London also sent more migrants to London than to the closer destinations. Table 5 presents estimates of migration flows in the $1890 \mathrm{~s}$ from four counties located as close or closer to other destinations than to

Table 5. Share of migrant flows from four southern counties to destination areas in the 1890s (\%).

\begin{tabular}{llllllr}
\hline County & London & Lancashire & Yorkshire & $\begin{array}{l}\text { West } \\
\text { Midlands }\end{array}$ & $\begin{array}{l}\text { East } \\
\text { Midlands }\end{array}$ & $\begin{array}{c}\text { South } \\
\text { Wales }\end{array}$ \\
\hline Oxford & 544 & 2.7 & 3.8 & 30.2 & 5.8 & $3-1$ \\
Northampton & 32.2 & $4-\mathrm{i}$ & 11.4 & 24.7 & 26.2 & $1-4$ \\
Wiltshire & 62.5 & 4.2 & 3.6 & 10.2 & 2.9 & 16.5 \\
Somerset & 40.7 & $3-7$ & $4-3$ & 9.2 & $3-7$ & 38.5 \\
\hline
\end{tabular}

London. Oxford was about equidistant from London and Birmingham, and yet sent far more migrants to London in the 1890s despite the fact that real wages in Birmingham were slightly above wages in London. Northampton was closer to the West and East Midlands than to London, but sent more migrants to London than to either destination, and Somerset was much closer to South Wales, and also was closer to Birmingham, than to London, but sent 41 per cent of its migrants to the metropolis, compared to 39 per cent to South Wales and only 9 per cent to the West Midlands.

The migration patterns from these counties in the 1890s cannot be explained simply by distance and destination wage rates, or, according to the regressions presented here, by migrants' preference for service sector employment. Part of London's success in attracting migrants was due to the size of its labour market and its disproportionate role as a creator of new jobs. Greater London was significantly larger than the other destinations,

27 The 26 southern residential towns include Bournemouth, Brighton, Hastings, and Poole. The 16 military towns include Canterbury, Colchester, Plymouth, and Portsmouth. 
and the regression results in column 2 show that a 10 per cent increase in destination population led to a 3.7 per cent increase in migration.

The results in Table 4 also suggest that the migration patterns of the 1890 s were strongly influenced by previous migration flows. For most of the nineteenth century, London wage rates were significantly higher than wages in the West or East Midlands or in South Wales, and as a result London attracted a large share of migrants from counties located closer to other destinations than to London. London remained the dominant destination for migrants from these counties in the 1890s despite the sharp increase in other destinations' wage rates, largely because the previous migrants living in London lowered the monetary and psychic costs of migration to the metropolis. Potential migrants from most of southern England in the 1890s were much more likely to have friends or relatives living in London than in any other destination. These friends and relatives provided information on job opportunities, as well as food and housing to recent migrants until they found employment. Smith (1892, p. 135) found that about half of the migrants to London that he was able to trace 'had definitely secured or ... [were] practically sure of a place' before they migrated, and that many of them had gone 'to join friends.' Anderson (1971, p. 155) wrote that 'kin and co-villagers were [the] main recourse' for the newly arrived migrant, who needed 'a roof over his head, a job, and someone to help him adjust to the new environment. ... The literature is full of references to inmigrants coming into the town, seeking out relatives or friends, and being sheltered and assisted by them.' Given the important roles played by previous migrants, it is not surprising that, other things equal, late nineteenth century migrants tended to follow the well-worn paths of earlier decades.

\section{The consequences of migration}

The regressions in Section 4 indicate that in late nineteenth century England the elasticity of migration with respect to the wage gap, a measure of labour mobility, was high, which supports Friedlander's (1992, p. 315) conclusion that migration in nineteenth century England was an 'effective means for the redistribution of the population and its labor force ... from areas of low to areas of higher productivity.' The high degree of labour mobility should have led to a reduction over time in rural-urban wage differentials. Economists often examine movements in regional or occupational wage differentials as a method for determining trends in labour market integration. ${ }^{28}$ Panel A of Table 6 presents estimates of the trend in the real wage gap between each origin county and London from 1861 to 1901. The numbers given represent the magnitude of the wage gap relative to the wage gap in 1861. For example, the Sussex-London wage gap in 1881 was 3.5 per cent smaller than the wage gap in 1861 . 
2io European Review of Economic History

Table 6. Changes in wage gaps between southern counties and London, 1861-1901.

Panel A: County wage gaps

\begin{tabular}{|c|c|c|c|}
\hline County & 1861 & 1881 & 1901 \\
\hline Sussex & 100.0 & 96.5 & 91.2 \\
\hline Hampshire & 100.0 & 112.0 & $99-5$ \\
\hline Berkshire & 100.0 & 104.4 & 99.2 \\
\hline Hertford & 100.0 & 77.8 & $74-9$ \\
\hline Bedford & 100.0 & 100.4 & $97-7$ \\
\hline Buckingham & 100.0 & 80.8 & 82.5 \\
\hline Oxford & 100.0 & 88.4 & 112.8 \\
\hline Huntingdon & 100.0 & 106.9 & $95-8$ \\
\hline Cambridge & 100.0 & $94-5$ & 101.5 \\
\hline Suffolk & 100.0 & 115.4 & 122.7 \\
\hline Norfolk & 100.0 & $94-5$ & 105.7 \\
\hline Wiltshire & 100.0 & 86.8 & 86.7 \\
\hline Dorset & 100.0 & 102.7 & 995 \\
\hline Devon & 100.0 & $74-6$ & $75-1$ \\
\hline Cornwall & 100.0 & 69.0 & 76.3 \\
\hline Somerset & 100.0 & 78.6 & 81.4 \\
\hline Northampton & 100.0 & 93.1 & $95-8$ \\
\hline Rutland & 100.0 & 106.0 & 87.6 \\
\hline Lincoln & 100.0 & 118.3 & 113.5 \\
\hline \multicolumn{4}{|c|}{ Panel B: Regional wage gaps } \\
\hline Region & 1861 & 1881 & 1901 \\
\hline Southeast & 100.0 & 105.4 & $95-9$ \\
\hline South & 100.0 & 90.3 & 92.3 \\
\hline East & 100.0 & 102.4 & no. 4 \\
\hline Southwest & 100.0 & $79-4$ & 81.1 \\
\hline Rural East Midlands & 100.0 & 108.1 & 105.9 \\
\hline
\end{tabular}

The major conclusion to be drawn from Table 6 is that, despite the large migration to London, for most southern counties the wage gap declined only slightly, if at all, during the late nineteenth century. Wage gaps in 1901 were larger than they had been in 1861 for 5 of the 19 counties, and declined by less than 5 per cent for 6 counties. On average, the wage gap between London and the rural South declined by 5 per cent from 1861 to 1901 . The entire decline occurred between 1861 and 1881; on average, the wage gap remained constant from 1881 to 1901.

Panel B of Table 6 presents estimates of the trend in the real wage gap at the regional level. ${ }^{29}$ The wage gap declined from 1861 to 1901 for the

${ }^{29}$ A region's real wage gap was calculated as a weighted average of the wage gaps for each county in the region. The weights used were the population of the county in 1901 . 
Southeast, South, and Southwest, and increased for the East and rural East Midlands. The largest decline by far occurred in the Southwest, where the wage gap was 19 per cent smaller in 1901 than it had been in 1861. For the 14 counties outside the Southwest, the real wage gap remained roughly constant from 1861 to 1901 .

The evidence concerning wage gaps does not appear to be consistent with the finding in Table 4 of a high degree of labour mobility. It is important to recognize, however, that wage rates in both origin counties and destinations were determined by forces besides labour migration, in particular shifts in labour demand. Hunt (1986, p. 958) has argued that 'the market forces that sustained [wage] differentials - in particular the spatial incidence of demand for labor and the indiscriminate nature of population increase - were so strong that substantial migration was necessary merely to prevent differentials increasing.'

The agricultural depression from the mid 1870s to the mid 1890s caused a particularly severe shock to the labour market in the grain-producing eastern counties. From 1871-4 to 1893-6, wheat prices declined by 57 per cent, barley prices declined by 40 per cent, and oats prices declined by 37 per cent (Mitchell and Deane 1962, pp. 488-9). The fall in grain prices, which caused assessments of land value to decline by over 30 per cent in each eastern county (O'Grada 1994, p. 164), also caused the demand for agricultural labour to decline sharply. ${ }^{30}$ It therefore is not surprising that the wage gap between the East and London increased by 10.4 per cent from 1861 to $1901 .^{31}$ Indeed, the fact that the average nominal wage of agricultural labourers in the East increased by 8 per cent from 1871 to 1901, at a time of falling labour demand, is far more surprising, and must largely have, been caused by the outmigration of 193,000 males from the eastern counties during this period (Baines 1985, pp. 287-8).$^{32}$

One can get a better idea of the important role played by migration by estimating how large rural-urban wage differentials would have been in 1901 if no migration had occurred between 1861 and 1901. It is possible to provide a rough estimate of the effect of migration on wage gaps using data on migration rates and assumptions about the demand elasticities for labour in agriculture and urban occupations. Williamson (1990, pp. 93-5) estimates that the long-run elasticity of labour demand in British nonagriculture was equal to -1.6. It seems reasonable to assume that the elasticity of labour

${ }^{30}$ The number of males employed in agriculture in the four eastern counties fell by about 26,000 from 1871 to 1901 , a decline of 17 per cent (Lee 1979).

${ }^{31}$ Lincoln, in the rural East Midlands, was also a major grain-producing county. The increase in the wage gap between the rural East Midlands and London from 1861 to 1901 was largely a result of the decline in the demand for farm labour caused by the agricultural depression.

32 As a result of the sharp decline in the cost of living, the average real wage of agricultural labourers in the East increased by 26 per cent from 1871 to 1901. 


\section{European Review of Economic History}

demand in agriculture was somewhat larger, say -2.0. The average male outmigration rates from the 19 southern counties for the four decades from 1861-70 to $1891-1900$ were 13.5 per cent, 15.5 per cent, 13.4 per cent, and 12.3 per cent. Assuming that the labour force participation rate (LFPR) of males in the population was 67 per cent, the LFPR of male migrants was 90 per cent, and the labour demand elasticity was equal to -2.0, if no outmigration had occurred between 1861 and 1901 then the average agricultural wage in 1901 would have been 32 per cent below its actual level. A similar calculation done for London, using estimates of net inmigration by Cairncross (1949, p. 83) and London employment data from Lee (1979), and assuming a labour demand elasticity of -1.6 , indicates that London wages would have been 24-28 per cent higher in 1901 if no inmigration had occurred between 1861 and 1901.

While these estimates are very rough, the conclusion to be reached from them is clear. The absence of a sharp decline in rural-urban wage gaps from 1861 to 1901 is not evidence of labour market failure. If there had been no rural-urban migration from 1861 to 1901, wage gaps in 1901 would have been much larger than their actual level.

\section{Conclusion}

This paper has addressed two issues concerning migration in southern England from 1861 to 1901: the determinants of migration flows between southern and eastern counties and six major destinations; and the effect of migration on rural-urban wage gaps. The results indicate that migration was driven by economic incentives, in particular: the magnitude of the benefits from moving, measured by the size of origin-destination wage gaps; the cost of moving, proxied by the distance between origin and destination areas; and the availability of information concerning urban job opportunities, proxied by distance and by the stock of individuals residing in a destination area who were born in the origin area. Previous studies of migration in Victorian Britain have stressed the importance of wage differentials and distance in determining migration patterns, but have largely ignored the role of past migration. This is unfortunate, because the evidence presented here suggests that potential migrants received assistance from friends and relatives who had previously migrated to a destination. This assistance, which reduced the monetary and psychic costs of migration, led to a perpetuation of earlier migration patterns, and helps to explain the continued dominance of London as a destination for migrants in the 1890s.

Migration flows were very responsive to wage differentials in late nineteenth century southern England. Despite the high labour mobility, ruralurban wage gaps on average declined only slighdy from 1861 to 1901. Rough estimates presented in Section 5 suggest that, in the absence of migration, wage gaps in 1901 would have been much larger than their actual level. It 
would appear that differentials in the growth in labour demand were so large that even a highly mobile labour force could not significantly reduce ruralurban wage gaps.

\section{Acknowledgments}

I thank Tim Hatton, George Jakubson, and two anonymous referees for helpful comments. All remaining errors are mine.

\section{References}

ANDERSON, M. (1971). Family Structure in Nineteenth Century Lancashire. Cambridge, UK: Cambridge University Press.

BAINES, D. E. (1985). Migration in a Mature Economy. Cambridge, UK:

Cambridge University Press.

BOARD OF TRADE, GREAT BRITAIN (1908a). Rates of Wages and Hours of Labour in Various Industries in the United Kingdom. Unpublished.

BOARD OF TRADE, GREAT BRITAIN (1908b). Enquiry into Working Class Rents,

Housing and Retail Prices. London: HMSO.

BOWLEY, A. L. (1898). The statistics of wages in the United Kingdom during the last hundred years. Part I: Agricultural wages. Journal of the Royal Statistical Society 61, pp. 702-22.

BOWLEY, A. L. (1901). The statistics of wages in the United Kingdom during the last hundred years. Part VIII: Wages in the building trades - concluded. Journal of the Royal Statistical Society 64, pp. 102-11.

BOWLEY, A. L. (1914). Rural population in England and Wales. Journal of the Royal Statistical Society 77, pp. 597-645.

BOYER, G. R. (1995). Wage convergence among low-skilled workers in late Victorian England and Wales. Unpublished paper.

BOYER, G. R. and HATTON, T. J. (1994). Regional labour market integration in England and Wales, 1850-1913. In G. Grantham and M. MacKinnon (eds), Labour Market Evolution. New York: Routledge.

BOYER, G. R., HATTON, T. J. and SOUTHALL, H. R. (1994). Regional labor markets in England and Wales, 1850-1914. Unpublished paper.

CAIRNCROSS, A. K. (1949). Internal migration in Victorian England. Manchester School 17, pp. 67-87.

EVERSLEY, LORD. (1907). The decline of the numbers of agricultural labourers in Great Britain. Journal of the Royal Statistical Society 70, pp. 267-319. FRIEDLANDER, D. (1974). London's Urban Transition 1851-1951. Urban Studies 11, pp. 127-41.

FRIEDLANDER, D. (1992). Occupational structure, wages, and migration in late nineteenth-century England and Wales. Economic Development and Cultural Change 40, pp. 295-318.

FRIEDLANDER, D. and ROSHIER, R. J. (1966). A study of internal migration in England and Wales: Part I. Population Studies 19, pp. 239-79.

GREENWOOD, M. J. (1972-3). The influence of family and friends on geographic 
labor mobility in a less developed country: the case of India. Review of Regional Studies 3, pp. 27-36.

GREENWOOD, M. J. and THOMAS, L. (1973). Geographic labor mobility in nineteenth century England and Wales. Annals of Regional Science 7, pp. 90-105. HARRIS, J. and TODARO, M. P. (1970). Migration, unemployment, and development: a two-sector analysis. American Economic Review 60, pp. 125-42. HILL, A. B. (1925). Internal migration and its effects upon the death-rates: with special reference to the county of Essex. Medical Research Council Reports 95. London: HMSO.

HUNT, E. H. (1973). Regional Wage Variations in Britain 1850-1914. Oxford, UK: Oxford University Press.

HUNT, E. H. (1981). British Labour History, 1815-1914. London: Weidenfeld and Nicolson.

HUNT, E. H. (1986). Industrialization and regional inequality: wages in Britain, 1760-1914. Journal of Economic History 46, pp. 935-55.

KERR, B. (1962). The Dorset agricultural labourer, 1750-1850. Proceedings of the Dorset Natural History and Archaeological Society 84, pp. 158-77.

LAWTON, R. (1967). Rural depopulation in nineteenth-century England. In R. W. Steel and R. Lawton (eds), Liverpool Essays in Geography. London.

LEE, C. H. (1979). British Regional Employment Statistics 1841-1971. Cambridge,

UK: Cambridge University Press.

LEE, C. H. (1984). The service sector, regional specialization, and economic growth in the Victorian economy. Journal of Historical Geography 10, pp. 139-55. LEVY, M. and WADYCKI, W. (1973). The influence of family and friends on geographic labor mobility: an international comparison. Review of Economics and Statistics 55, pp. 198-203.

mitchell, B. R. and Deane, P. (1962). Abstract of British Historical Statistics. Cambridge, UK: Cambridge University Press.

MORGAN, M. (1985). A model of internal and overseas migration by natives of English and Welsh counties, 1861-1900. In D. Baines, Migration in a Mature Economy. Cambridge, UK: Cambridge University Press.

O'GRADA, C. (1994). British agriculture, 1860-1914. In R. Floud and D.

McCloskey (eds), The Economic History of Britain since 1700, second edition, 2. Cambridge, UK: Cambridge University Press.

RAVENSTEIN, E. G. (1885). The laws of migration. Journal of the Royal Statistical Society 48 , pp. 167-227.

ROWE, J. W. F. (1928). Wages in Practice and Theory. London: Routledge.

SAVILLE, J. (1957). Rural Depopulation in England and Wales, 1851-1951- London: Routledge.

SHANNON, H. A. (1934-5). Migration and the growth of London, 1841-91.

Economic History Review 5, pp. 79-86.

SMith, C. T. (1951). The movement of population in England and Wales in 1851 and 1861. Geographic Journal 117, pp. 200-10.

SMITH, H. L. (1892). Influx of population - East London. In C. Booth (ed.), Life and Labour of the People in London, 3. London: MacMillan.

SOUTHALL, H. R. (1986). Regional unemployment patterns among skilled engineers in Britain, 1851-1914. Journal of Historical Geography 12, pp. 268-86. 
Southall, H. R. and Gilbert, D. M. (1996). A good time to wed? Marriage and economic distress in England and Wales, 1839 to 1914. Economic History Review 49, PP- 35-57-

TODARO, M. P. (1969). A model of labor migration and urban unemployment in less developed countries. American Economic Review 59, pp. 138-48.

VEDDER, R. K. and COOPER, D. (1974). Nineteenth century English and Welsh geographic labor mobility: some further evidence. Annals of Regional Science 8, pp. 131-9-

WEBER, A. (1899). The Growth of Cities in the Nineteenth Century. New York: Macmillan.

Williamson, J. G. (1990). Coping with City Growth during the British Industrial Revolution. Cambridge, UK: Cambridge University Press. 